\title{
A Catalyst for Change Language Socialization and Norm Negotiation in a Transient Multilingual Workplace \\ Lønsmann, Dorte
}

Document Version

Accepted author manuscript

Published in:

Journal of Linguistic Anthropology

DOI:

10.1111/jola.12162

Publication date:

2017

License

Unspecified

Citation for published version (APA):

Lønsmann, D. (2017). A Catalyst for Change: Language Socialization and Norm Negotiation in a Transient Multilingual Workplace. Journal of Linguistic Anthropology, 27(3), 326-343. https://doi.org/10.1111/jola.12162

Link to publication in CBS Research Portal

\section{General rights}

Copyright and moral rights for the publications made accessible in the public portal are retained by the authors and/or other copyright owners and it is a condition of accessing publications that users recognise and abide by the legal requirements associated with these rights.

\section{Take down policy}

If you believe that this document breaches copyright please contact us (research.lib@cbs.dk) providing details, and we will remove access to the work immediately and investigate your claim. 


\section{A Catalyst for Change: Language Socialization and Norm Negotiation in a Transient Multilingual Workplace Dorte Lonsmann}

Journal article (Accepted manuscript)

This is the peer reviewed version of the following article: A Catalyst for Change : Language Socialization and Norm Negotiation in a Transient Multilingual Workplace. / Lonsmann, Dorte. In: Journal of Linguistic Anthropology, Vol. 27, No. 3, 2017, p. 326-343, which has been published in final form at https://doi.org/10.1111/jola.12162.

This article may be used for non-commercial purposes in accordance with Wiley Terms and Conditions for Self-Archiving.

Uploaded to CBS Research Portal: January २०१९ 


\title{
A Catalyst for Change: Language Socialization and Norm Negotiation in a Transient Multilingual Workplace
}

\section{Dorte Lønsmann}

\author{
He came, not to fulfill prophesies, but to open the doors to new \\ futures. Such is ever the task of the catalyst.
}

— Robin Hobb, Assassin's Quest

\section{Introduction}

Internationalized workplaces are also often transient communities characterized by frequent changes in organizational structure and in employee composition. Departments are created, dissolved and moved, and employees are hired, moved, or reassigned. The constant influx of new employees entails a continuous process of initiation into workplace culture and workplace norms. Increasing internationalization of the corporate sector means that companies recruit internationally, post employees abroad and create virtual teams that collaborate across national borders. Such transient internationalized workplaces are typically highly linguistically diverse with several languages used for a variety of purposes. This means that among the workplace norms are norms for language use and language choice. Traditionally, language socialization means that a newcomer is socialized into existing cultural and linguistic norms. However, in these transient multilingual communities there may not be stable norms to be socialized into, instead new norms are continuously negotiated. This article investigates how a new employee is used as a catalyst for changing norms and practices in a transient multilingual workplace setting.

Garrett and Baquedano-López define (language) socialization as "the process through which a child or other novice acquires the knowledge, orientations, and practices that enable him or her to participate effectively and appropriately in the social life of a particular community" (2002:339). 
Despite the frequent mention of language socialization as a lifelong process in the literature, language socialization in the workplace remains relatively unexplored, as also noted in Roberts' (2010) review article. While some studies have focused on novices being socialized into a particular professional field, e.g. hair stylists (Jacobs-Huey 2003) or construction workers (Holmes and Woodhams 2013), studies focusing on language socialization in multilingual workplaces are scarce. Studies within critical ethnography, such as Goldstein's (1997) study of language practices among Portuguese factory workers in Toronto, and work done in call centres (Duchêne 2009, Heller 2002), shed light on how language competence can become a commodity in multilingual workplaces. These studies also explore how language ideologies, e.g. those stressing standardized bilingualism and professional language use, are connected to the distribution of power in the workplace (Duff 2008a:264), but they do not focus specifically on the processes of language socialization in multilingual workplaces. The few studies that do focus on language socialization in multilingual workplaces tend to concentrate on immigrants in blue-collar jobs as in the case of Duff et al.'s study of immigrant care aides in Canada (2002). In Baquedano-López and Mangual Figueroa’s (2011) review of studies of language socialization in immigration contexts, there is no mention of language socialization in work contexts. The authors do, however, call for new studies of bidirectional socialization that focus on how "immigrants groups influence the cities and locales they inhabit" (2011:555). While I agree with the need to focus on bi- or even multidirectional language socialization, and especially with a need to focus on how newcomers influence the setting they arrive in, I want to move beyond "immigrant groups" as this label does not reflect the complexity and diversity of international workplaces as sites of language socialization. Instead we need to look at how participants in transient multilingual settings, such as an international workplace, are socialized into the linguistic and cultural norms of the workplace, but also how their arrival can be a means to changing existing norms. 
Sociolinguistically oriented studies of language use in multilingual workplaces (e.g. Bellak 2014, Kingsley 2013, Lønsmann 2011) often take an ethnographic perspective and consider how the organizational context impacts language choice and language policy, but typically do not consider how language choice and language policy in return can contribute to changing organizational culture. Applying a language socialization perspective on language norms and language policy in multilingual workplaces allows us to see how language is connected with organizational culture, both as affected by the culture and as contributing to creating that culture.

The case I am analysing here focuses on language practices, policies and norms in a sixperson HR team in a large international company based in Denmark. At the time of the fieldwork the team was adjusting to the arrival of a new international employee who was the first non-Danishspeaking team member. The analysis focuses on the role of this new employee in bringing about changes in linguistic norms and organizational culture. This case allows me to explore how language socialization works in a transient multilingual community where norms are assumed to be less stable than in other kinds of communities. By engaging with language socialisation in the context of a transient multilingual workplace, the article contributes to exploring transience as an emerging research focus in sociolinguistics and linguistic anthropology.

\section{Transience and the negotiation of norms}

While "speech community" and later, "communities of practice" have been foundational theoretical constructs in much linguistic anthropological research, recently new forms of less stable communities are gaining increasing attention. In a contribution from the field of mobility studies, de Sapio discusses the evolution of transient communities in Victorian railway carriages (2013). De Sapio is interested in "the creation or improvisation of new social rules and roles governing interpersonal contact while on a rail journey" (2013:202). These communities are on the one hand 
characterized by fluidity, with the travellers coming together for a relatively short period of time and people in the carriage continuously being replaced along the journey. On the other, de Sapio also calls attention to the norms and roles people bring with them into these transient communities. In a sociolinguistic study also concerned with tourism, Jaworski and Thurlow (2010:255) argue for rethinking central sociolinguistic tropes such as "community" and "authenticity." In their study of fleeting encounters in heritage tourism in New Zealand and South Africa, they point to the importance of processes of "recontextualization" in these cross-cultural and multilingual encounters. Jaworski and Thurlow's analysis demonstrates not only how language is recontextualized for touristic purposes, but also how values, meanings and functions may remain stable across time and space, e.g. when their participants draw on common frames about gender roles. Compared to the kind of transience investigated in this special issue, de Sapio's transient communities are relatively short-lived and could more appropriately be characterised as "communities existing in the moment" as Jaworski and Thurlow (2010:281, emphasis in the original) label the interactions in their study. In these communities in the moment, participants have a larger need to draw on common frames since there is less time to develop shared meanings. Since the encounters are fleeting, there is less need to negotiate common norms and rules than in longerterm transient communities.

Mortensen (2013, 2014, this issue) introduces the concept of transient multilingual communities and considers as examples student project groups and international student cohorts as examples of such communities which are characterised by less stable norms for language choice than traditional speech communities or communities of practice. In transient multilingual communities, norms for language choice are not necessarily part of the communicative competence of members, but must be negotiated more or less explicitly in and through practice (Haberland 2007:139, Hazel and Mortensen 2013, Mortensen 2014:438- 
439). Mortensen conceptualises transience as a matter of degree, ranging from one-off encounters to more stable communities. The model introduced by Mortensen also captures the extent to which participants share semiotic resources in these more or less transient communities, from a shared language to shared higher order indexicalities (Mortensen, this issue). Lønsmann (2014:112) applies the concept of transient multilingual communities to an international corporation in order to illustrate the ever-changing linguistic diversity of such settings due to constant employee mobility. In one study, the notion of transience is coupled with a language socialization perspective: Goebel (2010) uses the transient multilingual setting of a linguistically diverse Indonesian neighbourhood as the backdrop for an investigation of language socialization. Similarly to Mortensen, Goebel points to the fact that rules and norms for conduct cannot be taken for granted in such a transient setting because participants do not share trajectories of socialization (2010:223). Like Jaworski and Thurlow, Goebel emphasises the importance of recontextualization, i.e. what happens when the meaning of signs is negotiated and changed in interaction. He concludes that learning depends on the extent to which the newcomer is able to appropriately recontextualize signs, in this case specific language alternation practices. While Goebel points out that "distinctions between newcomers and hosts continually change" in transient settings (2010:203), his analysis focuses on the socialization of a newcomer into the existing linguistic practices of the setting, and does not fully explore the importance of the transient setting for the language socialization process.

I suggest that in the context of multilingualism, it is beneficial to apply the concept of transience if we want to understand what is going on in terms of linguistic norm development and language socialization. By focusing on transient communities, this article also answers recent calls for problematizing traditional notions of the community in language socialization research (Garrett 
and Baquedano-López 2002:346-347) and for including more research on language socialization in "workplaces experiencing rapid changes in the norms of language use, especially with new, globalizing multilingual and multimodal discourses" (Duff 2008b:116). Focusing on the workplace context means that the article also contributes with an exploration of how transience may be embedded in a larger organisational context, and how the strategic element of language socialisation brought about by the organisational context interacts with the fluidity of the setting.

A key concept in this connection is norm negotiation. Linguistic norms can be understood as social conventions for language use (Blommaert 2006:502). As conventions, norms have an evaluative dimension to them. Furthermore, I see norms as context-bound, i.e. local and tied to the specific community, in this case the team. Knowing the norms of a specific context is part of what constitutes participants' communicative competence (Hymes 1972:63-64). Norms are not created in a vacuum, but "under the influence of a range of external factors at various levels of context" (Mortensen 2014:438-439), including societal norms and ideologies, institutional norms and group norms. In this study, societal language ideologies are one part of the context for norm negotiation in the team, while the organizational culture is another influence. While the team is transient, it nevertheless interacts within the more stable structure of the larger organization. As such the team is embedded in a particular organizational culture. In addition to this synchronic view on context, it is important to remember that when we talk about transience, we are talking about a trajectory. Members are moving into and out of the community, and this means that they carry with them norms and expectations from communities they have been part of before. These contexts influence norm negotiation as well.

This focus on negotiation entails an analytical focus on instances where norms are not followed in practice. Rather than seeing such instances as the breaking of a pattern (as has been the tradition in investigations of norms in stable speech communities (Hymes 2010:577)), the 
perspective on transience instead calls for the treatment of such instances as analytical "rich points" for the investigation of norm negotiation in action.

\section{Language socialization: Innovation of social order across the lifespan}

Schieffelin and Ochs originally defined language socialization as "socialization through the use of language and socialization to use language" (1986:163). In 2011, they specify the goal of language socialization research as understanding "the role of language $\ldots$ in the quotidian reproduction and innovation of social order and cultural knowledge, beliefs, values, ideologies, symbols, and indexes" (Ochs and Schieffelin 2011:11). Ochs and Schieffelin's definition thus stresses the potential of language socialization not just for reproducing the social order, but also for innovation of the social order and of cultural knowledge. In the transient multilingual workplace this would include the innovation and negotiation of new linguistic norms, but also negotiation of the workplace culture.

While the field of language socialization has always regarded language socialization as a lifelong process (Schieffelin and Ochs 1986), much early research focused on the child's socialization into a community. Ochs and Schieffelin (2011:5) argue that research into language socialization brings to the fore "how persons across the life cycle and across different generations are alike yet different, recognizable yet transformed, lending on-the-ground insight into how habitus and practice become durable, transposable, and restructured over time." Another shift in later research has been towards an emphasis on the dynamic and multidirectional aspects of language socialization (e.g. Bayley and Schecter 2003a, Duff 2008b, Ochs 1999). As Duff (2008b) points out, the "expert-novice" dichotomy is still frequently found in language socialization studies. The problem with the metaphor is that it erases the multi-directionality of language socialization, and overlooks the importance of personal histories and experiences in L2 language socialization. In 
addition, I want to add, newcomers often also bring with them firm expectations to language use in their new community, which also influence their attitudes and expectations to the new language practices they encounter and consequently also their language socialization. Bayley and Schecter emphasise the role of the novice as an active agent particularly in multilingual contexts where "the identity being formed is not one that has previously been available" (2003b: 6). The present article positions itself within these new perspectives with its focus on the multi-directionality of language socialization in a multilingual workplace.

\section{Methods and data}

The data for this article comes from an ethnographic case study conducted as a part of the LINGCORP project. During two months in 2013 I carried out participant-observation in an HR team in a Danish multinational company. I shadowed each team member for one or two days at work, participating in face-to-face meetings, lunch, and video conferences, and sitting next to them when they worked at their work stations in the open-plan office. I also carried out ethnographic interviews with five team members. The interviews took place in meeting rooms next to the informants' workspace and lasted between 43 and 72 minutes. The focus in the interviews was on informants' daily work, language use in the team and language barriers. I also collected a variety of written material, including employee magazines and language policy documents. In addition to the five full-time staff members, a Danish student assistant started working in the team during my fieldwork, but was not interviewed.

[Place Table 1 here] 
While the present work is inspired by earlier language socialization research, the methods and data diverge somewhat from traditional longitudinal ethnographic investigations of language socialization. The corporate setting where the data was generated did not allow for fieldwork spanning a period of years, and while I was allowed to observe team members at work, I did not have the opportunity to record these interactions. Consequently, the analysis relies to a large extent on interview data, i.e. metadiscursive accounts of what people say they do, rather than what they actually do. The ethnographic observations and the field notes provide a counterpoint to the interview data, however, in that they provide access to observed language practices.

The data analysis combines ethnographic domain analysis with linguistic micro-analysis of interviews and observational data. Using ethnographic domain analysis (Spradley 1979) entails a coding process where concepts are organized into domains and, subsequently, taxonomies, which are then further elaborated on in a componential analysis. The relevant domains found in the analysis included job types, nationality, team culture, language competence, languages, language use, motivations for language choice, language barriers, and strategies for overcoming the language barrier. Subsequent to the ethnographic analysis, the interview data was analysed using interactional sociolinguistic micro-analysis (Rampton 2006). Relevant sequences were identified by listening through the interviews repeatedly and were then transcribed by student transcribers. The subsequent microanalysis focused on producing detailed and comprehensive analyses of these key episodes of interaction (Gumperz 1999) by "drawing on a range of frameworks to describe both small- and large-scale phenomena and processes (e.g. pronunciation, grammar, genres, interaction structures, institutions, social networks)" (Rampton 2006:24). Since the ethnographic analysis had been completed at this stage, these results fed into the micro-analysis. 


\section{Analysis: Dynamic language socialization in a transient multilingual workplace}

The analysis is structured in four parts. The first part presents results from the ethnographic domain analysis with a focus on the transient nature of the workplace under investigation. The second part of the analysis focuses on the negotiation of norms, while the third part homes in on the role of the newcomer as a catalyst for changing norms and practices, more specifically how the arrival of a new employee leads to the increased use of English, and how increased use of English could lead to a change in workplace culture. In the fourth part of the analysis I consider how language socialization in this transient international workplace is meant to have multiple effects. Even as the newcomer is used to socialize 'old' employees into new international norms and practices, she is also being socialized into Danish workplace norms.

\section{A multilingual and transient workplace}

The HR team under investigation is a part of the production division of a large international company with 37,000 employees in more than 70 countries around the world. The manager and the four employees have degrees in communication, finance and linguistics. The people they communicate with are mostly managers at different levels, but also employees "on the floor," e.g. operators in the production facilities. The production division has facilities in five countries (Denmark, France, USA, Brazil and China), and the team members support these five sites with regard to HR, communication and training. This means that the majority of the team works with partners around the world in cross-cultural teams. The exception is Sally who only supports the Danish site. Most of the team's members have regular video conferences with their counterparts in the production facilities, as well as visits to and from the sites several times a year. Working in cross-cultural teams means that team members work multilingually. As Table 1 shows, all team members consider themselves proficient in English, have some Danish competence, and most of them also have competences in other languages. 
The team is seated in an open office space with teams from other departments. While there are no visible boundaries between teams, during my fieldwork the HR team never spoke to employees from the other teams, not even the employee whose desk was physically in the middle of the team. This type of invisible boundary is also in place when it comes to the hierarchical boundaries. As Sally, the new international employee, notes in her interview, Morten, the manager of the team, has a desk like everyone else with nothing like a separate office to indicate his position. Titles and hierarchy do appear to be important in the team and in the organization, however, as interviewees frequently refer to clear communication lines according to position in the hierarchy and a title structure specific for the company. Morten also positions himself as someone who takes his manager role seriously in his interview, talking about taking care of the welfare of his employees and setting strategic goals. With the exception of the two employees involved in training, the team members do not collaborate on a daily basis. Their tasks are quite separate and their closest collaborators are typically their partners on the five international sites. The communication partner Anna describes the team as "atomised," without common work tasks. All team members are very focused on their work, and they work a lot. They do not spend much time small talking. If they are not in meetings or travelling, they usually eat lunch together, but other than that there are no breaks. The team members seem aware that this sets them apart from other teams. When I ask about coffee breaks, Sally said, 'It's not like we do it regularly - that's what we don't do that everybody else does." This characteristic of the team begs the question of whether they really are a team since they do not collaborate on a day-to-day basis. They do, however, see themselves as a team. They have the occasional social event for the team as well as weekly team meetings. Importantly, they are designated a team in the organizational structure of the company.

A characteristic of not only this team, but the company in general is its transient nature. This international workplace is characterised by frequent organizational, human resource and spatial 
changes. People may work in the company for a long time, but not in the same position, department or country. Morten, Anna and Isabel have all moved around in the company since they were hired. During the period when I was in contact with the team - from first contact to feedback six months after the fieldwork - the composition of the team changed considerably. Sally was relatively new to the team when I met her, the student assistant Peter joined the team during the period, and Leif left for another position within the company towards the end of the period, as did Anna. When I came in to provide feedback, a new international team member had just started that day. Two years after the fieldwork, at the time of writing this article, only two of the team members were still in the HR team, while six new employees had joined the team. In addition, the team had moved to another area in the organization. From discussions of relocation and mobility in the meetings that I observed, this dynamic seemed typical also of other teams and employees in the company. Physically, the workplace was characterised by transience as well, as the team moved from one site to another a few kilometres away between the time of my fieldwork and my coming back to provide feedback. In both locations, the office was set up with everything on wheels. The shelves between the desks could be moved around, and there were very few stationary items in the open office. The team members each had their own desk in the office, but at the Danish production site (where Sally worked a couple of days a week), there was a system of rotating desks: Some desks had a red laminated card pegged to them with the text "Table not free" indicating that the rest of the tables were indeed free, and employees simply chose one when they came in in the morning and plugged in their laptop. This setup resembles the postmodern workspaces investigated by Andrews (2015) where the architecture and furniture are designed to reflect and shape a culture of flexibility. In the HR team, not only do employees move in and out of the team, but also the physical workspace is characterized by flexibility and fluidity. 
The multilingual and transient characteristics of this workplace are particularly pertinent when we look at linguistic norms and workplace culture. The following sections focus on how the transient multilingual setting influences linguistic and workplace norms.

\section{Negotiating norms for language choice}

As discussed above, transient settings are characterised by a lack of stable norms, which means that norms have to be negotiated continually. Before Sally joined the team, the norms for language use in the HR team had been pretty well established. The four Danish-speaking team members used Danish with each other and other Danish colleagues, and English for communicating across national borders, e.g. in video conferences with colleagues in other countries. Other languages were reportedly only used infrequently, something that had not changed by the time I did my observations, although team members reported using Mandarin Chinese, French and Spanish occasionally at work for social occasions and small talk. At the time of my fieldwork, Sally had recently started working in the team. Having grown up and gotten her education in mainly Englishspeaking countries, she was categorised by her co-workers as a non-Danish-speaker. In fact Sally had worked in Denmark before and had had a Danish boyfriend, and put down Danish on her list of language competences. In her interview she explained that she could understand most things in Danish, but only speak very little. Sally also explained that she had been told that English was the corporate language so she expected English to be the working language. For work purposes then, Sally was a non-Danish speaker. This change in the linguistic milieu led to a focus in the team on norms for language choice for team-internal communication. Morten explains in his interview:

Ex. 1 What does that do to a team?

1 MOR: så har vi øh diskuteret en hel masse nu hvor Sally hun er kommet til

2 det gjorde hun her i øh december måned det er egentlig første gang 
3 at vi har en ikke-dansktalende medarbejder i teamet

4 INT: ja

5 MOR: $\emptyset$ hm så der har vi der har vi brugt lidt energi på at tale hvad gør det

6 egentlig ved ved sådan et team

7 INT: $\quad \mathrm{mmh}$

8 MOR: $\emptyset \mathrm{h}($.$) der har vi så aftalt nu at \emptyset \mathrm{h}$ når Sally hun er her

9 så taler vi engelsk og det er også selvom Anna og Leif måske lige

$10 \quad$ sidder ind over bordet

$11 \mathrm{INT}:\lceil\mathrm{mmh}\rceil$

12 MOR: \og lige」 skal vende et eller andet omkring hvad skete der i weekenden

1 MOR: so we have uh discussed a lot now that Sally has joined us

2 she arrived in December this is actually the first time

3 that we have a non-Danish-speaking employee in the team

4 INT: yes

5 MOR: um so we have we have spent some energy talking about what does

6 that actually do to such a team

7 INT: $\mathrm{mmh}$

8 MOR: uh (.) we have agreed now that uh when Sally is here

9 then we speak English and that is also if Anna and Leif are leaning

$10 \quad$ over the table

11 INT: $\lceil\mathrm{mmh}\rceil$

12 MOR: [ just] chit-chatting about something that happened over the weekend 
Morten here explicitly spells out the new norm for language choice: "when Sally is here then we speak English" (11. 8-9), even if two Danes are discussing something not work-related. The way this rule came into being is not clear. Morten says that they have spent some energy talking about this issue and that they "have agreed." This makes it seem like the other team members are on board and agree with the new norm. In practice, however, language choice was still up for negotiation. Anna relates an interaction where she addressed Morten in Danish, and he responded: "Oh, remember English!". What we can see here is a case where existing linguistic norms are changed by the arrival of a new team member. Instead of Sally being socialized into the existing linguistic norm (speaking Danish in the team), the team is being socialized into her language practices (speaking English). The Danish-speaking team members were already using English in the daily collaboration with the five production sites, so speaking English was not new to them. Speaking English in the team, however, was new and seen as potentially problematic, as evidenced by Morten's statement that they had "spent some energy" talking about it. Morten also made it clear that one reason I was allowed access to the team to conduct fieldwork was because he hoped they would get some input on "making a language policy" and on how to "handle there being different nationalities in a team."

As discussed above, the status of these employees as "a team" is perhaps debatable. Their tasks only rarely overlapped, and they were so focussed on their work that they spent very little time small talking or hanging out. Perhaps one reason that the team was so eager to discuss and negotiate norms of interaction is that such norm negotiation is a way of building a sense of community and togetherness in an otherwise fragmented team. Such negotiations functions as a way of talking themselves into being as a team, while the resulting language policy may function as a roadmap to follow in an "atomised" and ever-changing working life.

While the norm was to use English around Sally, it was also clear that following the norm in practice is not without challenges. The observational data reveal that both Danish and English were 
used in the office. Sally herself never used Danish, only English. The other team members spoke Danish when Sally was not there, and either Danish or English when she was. In one example from my field notes Leif and Isabel talk about training-related communication in Danish while Sally sits next to them at her desk. Later the same day, however, they have a similar conversation in English. Most of the written communication, e.g. PowerPoint slides and emails were in English. The other employees in the open office spoke mostly Danish.

Interestingly it was not Sally who did most of the explicit language socialization, in fact she was quite restrained about it with her colleagues. She talks at length in her interview with me about feeling excluded due to the use of Danish in the team. The Danish team members also talk about the fact that Danish is used in the team despite the explicit agreement to use English around Sally. Anna says in her interview that she sometimes forgets to speak English and that this is something they need "to concentrate on more." Sally has not, however, brought this up with her colleagues directly. Instead she used more indirect ways of socializing them into the new norm:

Ex 2. I mentioned someone else

1 SAL: I brought it up in a (0.6) through a different way

2 I mentioned someone else (.) who was in uh my area

3 who is also experiencing the same 「 thing $\rceil$ and I also (0.5)

4 INT: [ yeah]

5 SAL: tried to get their feedback on ta ta ta ta

Here, Sally introduced the problem of being excluded because of the use of Danish as though it were really a friend's problem and asked her co-workers to reflect on the issue. When Sally tries to socialize her colleagues by telling the story of a friend of hers who has problems, it resembles what 
Goodwin and Kyratzis (2011:367) describe with children who police the local social landscape using gossip and hypothetical stories. Another strategy Sally relied on is silence:

Ex. 3 Then they kind of notice

1 SAL: $\quad$ sometimes (0.6) things continue in Danish (1.0) but then

2 you know I'm (.) quiet then they 「 kind] of notice

3 INT: \yeah

That norms were still being negotiated can also be seen from Sally's experiences with co-workers trying to socialize her into the "old" norms:

Ex. 4 When are you gonna start speaking Danish?

1 SAL: $\quad$ sometimes they say oh when are you gonna start speaking Danish

2 INT: yeah

3 SAL: $\quad$ and (.) I feel a bit like okay so I should $\odot$ be the one to $\odot$ change first

These examples highlight the norm negotiation process initiated by Sally's arrival, and also the differences between linguistic norms and practices. When the team composition changed from all Danish-speakers to including a perceived non-Danish speaker, it occasioned a series of negotiations where team members talked about having a non-Danish-speaking team member, what this would do to the team, and what the norm should be for language choice. Subsequently, the team members socialized each other into the new norm, using a range of strategies from explicitly correcting each other to more subtle cues. At the same time, the language practices were at times closer to the old 
norm, visible when co-workers explicitly socialize Sally into acknowledging the position of Danish in the workplace.

\section{Changing the norms by bringing in a catalyst}

During my fieldwork I wondered why the team members saw "English only" as the most obvious solution to the challenges presented by the new linguistic constellation in the team. When I looked further into this, it appeared that changing the language was not the end goal of the socialization process, rather it was seen as a means to a different end: Increased internationalization in the team and in the organization.

Three months after the end of the fieldwork, two team members attended a seminar on language policy with the researchers from the LINGCORP project. Subsequently the team members created a language policy for their team, which mandated that "English is spoken whenever a nonDane is present - including informal talk," and that they all "commit to bring it to attention when Danish is spoken with a non-Dane present." The policy had "inclusion of non-Danish employees" as its explicit purpose. In addition, however, the language policy also states as a goal to "develop a global mind-set." Increased internationalization was an explicit goal not just of this team, but of the wider organization. The company had a diversity key performance indicator which in addition to setting a goal for the gender ratio in high level management groups also dictated the inclusion of at least one non-Dane in these groups. In addition, a project in the production division focused on integrating "international talents" in the Danish HQ organization. Part of the goal of this project was to allow an exchange of values between Danes and non-Danes. Morten talks about the success of bringing a Chinese employee to a remote location in Denmark:

Ex. 5 A catalyst for the international mindset

1 MOR: vi har en kineser i Hjørring af alle steder ik 
2 INT: ha ha ha

3 MOR: altså (.) Hjørring [ ha ha]

4 INT: $\quad\lfloor$ ja

5 MOR: $\quad \phi h m(0.8)$ og det var (0.5) altså (0.7) @outrageous $\odot$ da der var nogle

6 der foreslog at vi skulle have en kineser en kinesisk kvinde til Hjørring

7 INT: ja ha

8 RES: men det har bare betydet rigtig meget for Hjørring-organisationen

9 INT: okay

10 MOR: fordi de har (.) de har kastet sig ind i kampen og sagt okay jamen

11 øh så må vi jo øh så vi sætte os ind i hvad betyder det egentlig

12 at være kineser

13 INT: $\mathrm{mmh}$

14 MOR: $\quad$ hm så må vi begynde at arbejde noget med noget engelsk så må vi

15 begynde at skrive på engelsk og så videre

16 INT: $\mathrm{mmh}$

17 MOR: så på den måde er det egentlig også en katalysator [ for $\rceil$ h for hvad hedder

18 INT:

$\lfloor\mathrm{mmh}\rfloor$

19 MOR: det $\emptyset \mathrm{hm}$ (1.3) for og og og og drive på med den her (.)

20 det her mere internationale mindset

1 MOR: we have a Chinese person in Hjørring of all places right

2 INT: ha ha ha

3 MOR: you know (.) Hjørring [ ha ha†

4 INT: 【 yeah」 
5 MOR: um (0.8) and that was (0.5) you know (0.7) $)$ outrageous $(-)$ when someone suggested that we should get a Chinese a Chinese woman to Hjørring

7 INT: yes ha

8 RES: but it has just meant a lot to the Hjørring organization

9 INT: okay

10 MOR: because they have (.) they have thrown themselves into the game and said okay

11 well uh then we have to uh then we have to familiarize ourselves with what does

12 it actually mean to be Chinese

13 INT: $\quad \mathrm{mmh}$

14 MOR: um then we will have to start working with some English then we will have to 15 start writing in English and so on

16 INT: $\mathrm{mmh}$

17 MOR: so in that way it is actually also a catalyst [ for $\rceil$ uh for what is it called 18 INT: $\lfloor\mathrm{mmh}\rfloor$

19 MOR: um (1.3) for for for getting on with this (.) this more international mindset

Morten here describes how the Chinese employee in Hjørring (seen from the capital as an almost laughably remote provincial location, as evidenced by the interaction in 11. 1-7) functions as a catalyst both in terms of increased cultural awareness (11. 11-12), but also as a catalyst for changes in language use and norms (11. 14-15) and ultimately for a change in organisational mindset towards a more international one (11. 19-20). Underlying the apparent leap from "Chinese employee" to "working with some English" is the well-described ideology of English as the only language for international communication (Lønsmann 2015; 
Millar et al. 2013). A related ideology equates international with English (Lønsmann 2011), as is also seen in this excerpt when Morten moves from describing a change in language practices to more English to "getting on with this (.) this more international mindset" (11. 1920).

As the language policy showed, increased internationalization in the form of developing "a global mind-set" is also a priority in the HR team. What a global mindset is is not clearly defined, and Morten's hesitation in lines 17-20 in Ex. 5 seems to indicate that he is not even sure what to call it. However, this global or international mindset seems to include a willingness to use English and an understanding of other cultures. In another excerpt from Morten's interview, he defines "an international mindset" in contrast with "being quite Danish in Denmark and quite Chinese in China." In their study of language ideologies in multinational corporate companies, Angouri and Miglbauer (2014: 160) refer to a "cosmopolitan ideal" which appears similar to the global mindset that my informants talk about. The managers in their study claim a cosmopolitan identity which is associated with diverse cultures and languages, and with the ability to move back and forth between languages and environments. The "global mindset" appears to be an overarching idea which informs norms and practice, while also being the end goal of the language policy. As such "the global mindset" can be described as an ideology, and to the extent that it encompasses positive valorisations of the use of "English only" a language ideology which sees internationalisation as not only a positive, but as a necessary process, inextricably linked with the use of English.

In this way English becomes an emblem of internationalisation and the global mindset. A recent study of language ideologies in international workplaces in Europe has shown that English is seen as the one and only language of internationalization (Lønsmann 2015). Work 
by Angouri (2013), Nekvapil and Sherman (2013), and Millar et al. (2013) also confirms the privileged role of English in international workplaces at the level of language ideologies (though not necessarily in practice). Furthermore, Lønsmann (2015:351) shows that the degree of internationalization of a company often is discussed in terms of the amount of English used. This helps us to understand why the Danes in the company I studied simultaneous agree to an English-only policy and try to socialize Sally into using Danish at work. Kraft and Lønsmann (forthcoming) demonstrate how the ideology of Danish as the "natural" language to use in Denmark and the ideology of English as the "natural" language for international communication are part of the same language ideological landscape.

Like the Chinese employee in Hjørring, in Morten's team the new international employee is also positioned as a catalyst. In order to attract non-Danes to apply, the job description for Sally's position specifically stated that Danish competence was not necessary. In the section that follows immediately after Ex. 5, Morten explains how this was useful to him:

Ex. 6 A tool to set an agenda

1 MOR: og det var det samme jeg sagde til Sally da jeg rekrutterede hende så sagde jeg Sally jeg ved det det bliver sikkert hårdt for dig

3 INT: ja

4 MOR: men du skal være opmærksom på at grunden til at jeg tager dig

5

6

7

8 INT: som HR partner ind i den danske del af organisationen er fordi at du kommer også til at være et redskab for mig til og og sætte en agenda og [drive en]

$$
\lfloor\mathrm{mmh}\rfloor
$$


9 MOR: agenda

10 INT: ja

11 MOR: som jo så betyder nu at i det led de ledelsesgrupper Sally hun

12 sidder jamen der taler de også engelsk nu 「lige† pludselig ikk'

13 INT:

$\lfloor j a\rfloor j a$

14 MOR: hvilket de aldrig har gjort før

15 INT: så det kan godt altså så der er også den agenda med [og]

16 MOR:

$\lfloor\mathrm{ja}\rfloor$

17 INT: rekruttere 〔 interna] tionalt

18 MOR: \ja」

1 MOR: and it was the same thing I said to Sally when I recruited her

2 I said to Sally I know it will probably be hard for you

3 INT: yes

4 MOR: but you have to know that the reason that $\underline{I}$ am taking you in

5 to be HR partner in the Danish part of the organization

6 is because you will also be a tool for me

7 to to to set an agenda and [ drive an]

8 INT: $\lfloor\mathrm{mmh}\rfloor$

9 MOR: agenda

10 INT: yes

11 MOR: which means that now in the management groups Sally she

12 is in well there they also speak English now [ suddenly] right

13 INT:

【yes」 yes 
14 MOR: which they never did before

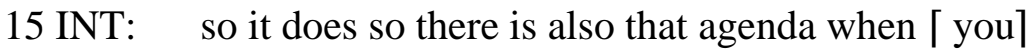

16 MOR:

17 INT: recruit [interna] tionally

18 MOR: \yes \

Morten here calls Sally "a tool to set an agenda" of internationalization. In 11. 11-14 it becomes clear that bringing Sally in to work in a Danish part of the organization had two, linked goals: to prompt a change in linguistic practice and to bring about a more global mindset, both among the people Sally supports as an HR partner and in the team. Sally's presence functions as a kind of implicit language socialization that is backed up by formal and explicit language policy about the use of English.

While being an international employee in an increasingly globalized workplace comes with a certain prestige, it is not always easy being a catalyst. As the first non-Danish speaker in the team, Sally is being used as a trailblazer, i.e. the burden of making people change is on her. Sally talks about feelings of exclusion when the Danes talk over her head in Danish. In her interview, while she claims to understand most things in Danish, she consistently constructs herself in the same way as Morten does: as a non-Danish speaker at work. Consequently, her colleagues' use of Danish in her presence makes her feel that they do not respect her and that she is not important enough for them to make the effort to speak English. Thus on the one hand, Sally has status as an expert member of the community of English speakers. She has the "right" (English) language practices and the "right" (global) mindset. On the other hand, she is a newcomer in the country and the company, and a minority in the team. This puts her at a disadvantage compared to the Danish-speaking majority who have 
also been at the company longer. As an international newcomer she occupies at the same time highly valued and relatively powerless positions.

\section{Socialization into Danish workplace norms}

As we saw above, international newcomers can function as catalysts for socializing others into new English-speaking practices, but the international employees are at the same time socialized into Danish and company-specific work practices and discourses. While integrating international talents into the Danish organization is done partly with the aim of making the Danish organization more international, there is also another side to the socialization process. Anna, who is a communication specialist and also part of the management team in the division, explains the importance of "transfer of values":

Ex. 7 It has to do with transfer of values

1 ANN: vi vil meget gerne have nogle af de udenlandske (.) ind i den danske organisation sådan så 「 de] også kan

3 INT: $\lfloor\mathrm{ja}\rfloor$

4 ANN: blive set af den danske organisation og (.) har det også noget med

5 noget sådan rent $\emptyset \mathrm{h}$ værdimæssige overførsel og sådan noget så (0.3)

6 så vi vil gerne have altså at der er en udveksling mellem dansk og

$7 \quad$ ikke danskere

8 INT: så når du siger værdimæssige overførsel og du snakker også om 9 the [company] way

10 ANN: ja men det er the [company] way vi taler om når jeg

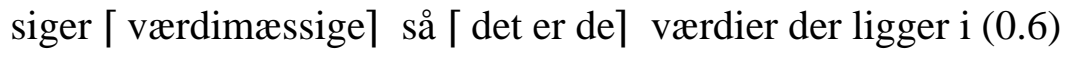




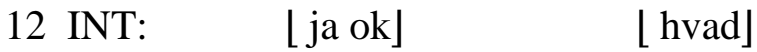

13 ANN: jamen vi behandler alle med respekt for eksempel vi har en $\emptyset \mathrm{h}(0.5)$

14 en $\varnothing \mathrm{h}$ åben og ærlig $\varnothing \mathrm{h}($.$) kultur (0.6) vi ø \mathrm{hm}(0.7)$

15 vi går aldrig på kompromis med sikkerhed eller med at business ethics

$16\lceil$ ○g $\rceil$ kvalitet altså $(0.5)$

17 INT: 【hm:」

18 ANN: det det er alle de der vores essentials

1 ANN: we would really like to get some of the foreigners (.) into the Danish organization so that $[$ they $]$ can also

3 INT:

【yes」

4 ANN: be seen by the Danish organization and (.) it also has to do with

$5 \quad$ purely uh transfer of values and things like that so (.)

6 so we do want there to be an exchange between Danes and

7 non-Danes

8 INT: $\quad$ so when you say value transfer and you also talk about

9 the [company] way

10 ANN: yes but it is the [company] way we are talking about when I

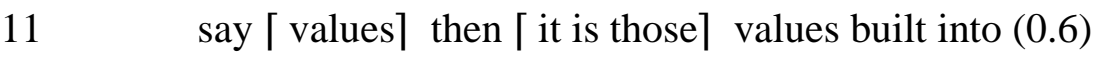

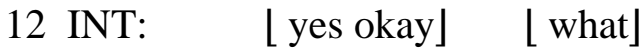

13 ANN: well we treat everyone with respect for instance we have a uh (0.5)

14 an uh open and honest uh (.) culture (0.6) we um (0.7)

15 we never compromise when it comes to safety or business ethics

16 「and $\rceil$ quality you know (0.5) 
17 INT: \hm:」

18 ANN: that those are all our essentials

The interviewer and Anna refer to "the [company] way" and "our essentials," both labels for a set of values set out on the company website. While these values are already promoted in the global corporation, Anna here argues that the physical presence of international employees in Denmark and an exchange between Danes and non-Danes will lead to the transfer of these company values to the group of international employees who she later refers to as "talents."

This type of socialization is also visible at the micro level in the team interactions. One Danish company norm that attracted Sally's attention as different from her own expectations is the relatively flatter hierarchy, exhibited in the way that the role of the manager is enacted. In the interview she noted her surprise that the manager just has a desk like everyone else, not his own office. She also struggled with the more assertive communication style required from her in the Danish setting. When she told Morten, her manager, about feeling excluded because her co-workers spoke Danish around her, she was disappointed by his response:

Ex. 8 It should be my manager setting the frame

1 SAL: I've had a conversation with Morten um (0.6)

2 in the beginning that okay (0.7) you know I felt something (.)

3 about it (0.7) um and he suggested I (.)

4 that I address my t- team (0.8) about it and (.)

5 I felt a little bit strange about that

6 INT: yeah

7 SAL: um (.) but (.) you know but then I (0.7) 
8 I didn't really address it I didn't feel that comfortable (.)

9 being the one addressing [ that]

10 INT: $\lfloor\mathrm{hmm}\rfloor$

11 SAL: it should be my manager I think (.)

12 INT: yeah

13 SAL: setting (0.7) the guidelines or 「 setting $\rceil$ the frame

14 INT: $\quad$ [yeah

15 SAL: for- (0.9) for uh us working here

Sally believes it is the manager's job to set the guidelines, but Morten suggests that she herself "address the team about it." Sally recounted that her Danish colleague Anna also encouraged her to “just tell us to stop" speaking Danish, but said that doing so would be uncomfortable for her: "I mean I'm not gonna be like hello every five seconds if they start speaking Danish you know.” But actually this is exactly what Morten and Anna are trying to teach her to do. Morten touches on exactly the same issue in his interview: How to handle the situations where Danes forget to speak English around Sally:

Ex. 9 Please tell us when we slip up

1 MOR: det tror jeg er noget af det som $\varnothing$ h som $\varnothing$ h som er vigtigt for mig

2 at jeg sammen med mine danske kollegaer og medarbejdere får vist Sally

3 at altså vær nu sød og øh og og vi altså lov os nu at du siger

4 når vi nu falder i ikke for det sker jo

1 MOR: I think that is part of what uh what uh is important for me 
This short excerpt makes two different norms explicit. The first is the linguistic norm for speaking English around Sally, which Morten here ratifies by saying that he encourages Sally to admonish people who forget. The second norm is an organizational norm detailing who should take responsibility for making sure people follow the linguistic norms. Morten here makes it clear that the norm is that Sally herself should speak up, and that he is trying to teach her this. So while Sally functions as a catalyst for changing language practices in a more international direction, she is at the same time being socialized into Danish (or perhaps company-specific) work culture and norms, specifically into a different management style than she is accustomed to and to a more assertive communication style. In this transient multilingual workplace, socialization works in two ways: The new international employee is being socialized into the Danish working culture, but the rest of the team is being socialized into new, more international language practices and a more global mindset.

\section{Discussion and conclusion}

This article has investigated language socialization in an internationalizing workplace with a particular focus on the importance of the transient and multilingual nature of that workplace. In this discussion I want to focus on three contributions from the study. The first is the analysis of the "global mindset" and its link to ideologies of English as a global language. The second contribution relates to the role of transience in studies of language socialization, particularly the introduction of the catalyst effect. Thirdly, I want to discuss how power and status affect language socialization in a workplace setting. 
First, we have seen the simultaneous and two-way process by which Danish employees were socialized into a global mindset through the use of English and the international newcomer was socialized into Danish and company-specific workplace culture and norms. In their definition of socialization, Garrett and Baquedano-Lopez (2002:339) emphasise the end goal of the process as enabling members to participate effectively and appropriately in the community. In order to participate effectively and appropriately as defined by both old and new company norms and values, members needed both linguistic norms and practices associated with an international workplace and knowledge and acceptance of an egalitarian workplace culture where employees speak up for themselves and the manager takes a more withdrawn role.

The explicit goal of introducing a global mindset in the team and in the organization at large took place over time and involved a three-stage process: First, the company increased the number of international employees in the Danish sites, both through strategic recruitment and through increased exchange. In this first stage the employee group changed from Danish to international. In the second stage the new international employees were used as catalysts to make the whole employee group speak (more) English, i.e. at this stage language practices changed from Danish to English. A range of language socialization strategies was used at this stage, including explicit admonishing and the subtle use of silence. In the third stage, the presence of international colleagues and the increased use of English supposedly moved employees from a Danish to a global mindset. What exactly a global mindset looks like, and how it furthers the goals of the organization remain relatively unclear. It is clear, however, that "the global mindset" reflects a core assumption that internationalisation is not only a positive, but a necessary process, and a language ideology that links this process inextricably with the use of English. 
Finally, the data show that in a transient context, language socialization is not just dynamic and multidirectional, but may actually have a change of norms as the end goal. This is an important counterpoint to previous studies showing language socialization as a way to reproduce existing norms in "stable" communities. This means that while the transformative potential of language socialization is usually applied in relation to changing a newcomer from novice to expert, in the context of the transient multilingual workplace, multiple types of expertise can be valued and located in both existing members and newcomers. This two-way transformative potential is brought about by the co-existence of two factors: transience and linguistic and cultural diversity. The transient setting itself as described in the first part of the analysis made change not just possible but desirable for an organization that had already charted a trajectory towards a new future. The diverse linguistic and cultural resources brought in by Sally (and to some extent personified by Sally) brought about the actual change in norms and practices.

Sally's case also shows that language socialization in the transient multilingual workplace is closely tied with organizational structures determining the roles, power and agency of individual employees. The strategic aspect of the language socialization process described here differs from much of the literature on language socialization outside the workplace where it typically does not happen with a strategic goal in mind. These results suggest a need for further exploration of language socialization processes in institutional contexts, including multilingual and transient workplaces and a need for further investigation of how status and power are linked with language socialization. While her "international" identity and non-Danish language practices are seen as a resource for "opening the doors to new futures" by Morten and the organization at large, for Sally her position as catalyst is linked with feelings of exclusion and lack of respect from her Danishspeaking colleagues. While her status as an expert English speaker with the right global mindset could be seen as a conferring power on Sally in the context of an internationalizing workplace, she 
is still a minority in a Danish majority workplace. Furthermore, her role as a catalyst does not make Sally herself powerful, but rather, makes her a powerful tool for the people who use her as such. Through Sally, the team manager has the power to change practices, norms and perhaps the mindset, but Sally herself is relatively powerless as the sole non-Danish speaker in a Danish workplace and very exposed as the catalyst who brings about change.

\section{Acknowledgements}

This research was carried out as part of the project An Ethnography of Language Encounters: Language and Interaction in the Globalized Corporation (LINGCORP) which was funded for the period 2012-2016 by the Danish Council for Independent Research. See more at lingcorp.ruc.dk. The author would like to thank the participants at the LINGCORP 2015 workshop and the two anonymous reviewers for valuable comments and insights.

\section{References}

Andrews, Deborah C.

2015 The Physical Environment for Communication in 21st-Century Work Spaces: A Research Model. In The Ins and Outs of Business and Professional Discourse Research: Reflections on Interacting with the Workplace. Glen Michael Alessi and Geert Jacobs, eds. Pp. 37-62. Houndmills: Palgrave Macmillan.

Angouri, Jo

2013 The Multilingual Reality of the Multinational Workplace: Language Policy and Language Use. Journal of Multilingual and Multicultural Development 34(6):564-581.

Baquedano-López, Patricia, and Ariana Mangual Figueroa 
2011 Language Socialization and Immigration. In The Handbook of Language

Socialization. Alessandro Duranti, Elinor Ochs and Bambi B. Schieffelin, eds. Pp. 536563. Malden: Wiley-Blackwell.

Bayley, Robert, and Sandra R. Schecter, eds.

2003a Language Socialization in Bilingual and Multilingual Societies. Clevedon:

Multilingual Matters.

Bayley, Robert, and Sandra R. Schecter

2003b Toward a Dynamic Model of Language Socialization. In Language Socialization in Bilingual and Multilingual Societies. Robert Bayley and Sandra R. Schecter, eds. Pp. 1-

8. Clevedon: Multilingual Matters.

Bellak, Nina

2014 Can Language Be Managed in International Business? Insights into Language Choice from a Case Study of Danish and Austrian Multinational Corporations (MNCs). Ph.D. dissertation, Department of International Business Communication, Copenhagen Business School.

Blommaert, Jan

2006 Language Ideology. In Encyclopedia of Language and Linguistics. $2^{\text {nd }}$

Edition vol. 6. Keith Brown, ed. Pp. 510-522. Oxford: Elsevier.

de Sapio, Joseph

2013 Transient Communities: Travel, Knowledge, and the Victorian Railway Carriage, 1840-90. Mobilities 8(2):201-219.

Duchêne, Alexandre

2009 Marketing, Management and Performance: Multilingualism as Commodity in a Tourism Call Centre. Language Policy 8(1):27-50. 
Duff, Patricia A.

2008a Language Socialization, Higher Education, and Work. In Encyclopedia of Language and Education $2^{\text {nd }}$ Edition vol. 8. Patricia A. Duff and Nancy H. Hornberger, eds. Pp. 258-270. New York: Springer.

2008b Language Socialization, Participation and Identity: Ethnographic Approaches. In Encyclopedia of Language and Education $2^{\text {nd }}$ Edition vol. 3. Marilyn Martin-Jones, A. M. de Mejia and Nancy H. Hornberger, eds. Pp. 107-119. New York: Springer.

Duff, Patricia A., Ping Wong, and Margaret Early 2002 Learning Language for Work and Life: The Linguistic Socialization of Immigrant Canadians Seeking Careers in Healthcare. The Modern Language Journal 86(3):397422.

Garrett, Paul B., and Patricia Baquedano-López

2002 Language Socialization: Reproduction and Continuity, Transformation and Change. Annual Review of Anthropology: 339-361.

Goebel, Zane

2010 Language, Migration, and Identity: Neighborhood Talk in Indonesia. Cambridge: Cambridge University Press.

Goldstein, Tara

1997 Two Languages at Work: Bilingual Life on the Production Floor. New York: Mouton de Gruyter.

Goodwin, Marjorie H., and Amy Kyratzis

2011 Peer Language Socialization. In The Handbook of Language Socialization.

Alessandro Duranti, Elinor Ochs and Bambi B. Schieffelin, eds. Pp. 365-390. Malden: Wiley-Blackwell. 
Gumperz, John J.

1999 On Interactional Sociolinguistic Method. In Talk, Work and Institutional Order. Srikant

Sarangi and Celia Roberts, eds. Pp. 453-472. Berlin: Mouton de Gruyter.

Haberland, Hartmut

2007 Language Shift in Conversation as a Metapragmatic Comment. In Metapragmatics in

Use. Wolfram Bublitz and Axel Hübler, eds. Pp. 129-140. Amsterdam: Benjamins.

Hazel, Spencer and Janus Mortensen

2013 Kitchen Talk - Exploring Linguistic Practices in Liminal Institutional Interactions in a Multilingual University Setting. In Language Alternation, Language Choice and Language Encounter in International Tertiary Education. Hartmut Haberland, Dorte Lønsmann and Bent Preisler, eds. Pp. 3-30. Dordrecht: Springer.

Heller, Monica

2002 Globalization and the Commodification of Bilingualism in Canada. In Globalization and Language Teaching. David Black and Deborah Cameron, eds. Pp. 47-63. New York: Routledge.

Holmes, Janet and Jay Woodhams

2013 Building Interaction: The role of Talk in Joining a Community of Practice. Discourse \& Communication 7(3):275-298.

Hymes, Dell

1972 Models of Interaction of Language and Social Life. In Directions in Sociolinguistics. The Ethnography of Communication. John J. Gumperz and Dell Hymes, eds. Pp. 35-71. New York: Holt, Rinehart and Winston. Hymes, Dell 2010(1963) A Perspective for Linguistic Anthropology. Journal of Sociolinguistics 
14(5):569-580.

Jacobs-Huey, Lanita

2003 Ladies are Seen, not Heard: Language Socialization in a Southern, African American

Cosmetology School. Anthropology and Education Quarterly 34:277-299.

Jaworski, Adam, and Crispin Thurlow

2010 Language and the Globalizing Habitus of Tourism: Toward a Sociolinguistics of

Fleeting Relationships. In The Handbook of Language and Globalization. Nikolas

Coupland, ed. Pp. 255-286. Malden: Wiley-Blackwell.

Kingsley, Leilarna

2013 Language Choice in Multilingual Encounters in Transnational Workplaces. Journal of Multilingual and Multicultural Development 34(6):533-548.

Kraft, Kamilla and Dorte Lønsmann

in press. A Language Ideological Landscape: The Complex Map in International Companies in Denmark. In English in Business and Commerce: Interactions and Policies. Tamah Sherman and Jiř́i Nekvapil, eds. Berlin: de Gruyter.

Lønsmann, Dorte.

2011. English as a Corporate Language. Language Choice and Language Ideologies in an International Company in Denmark. Ph.D. dissertation, Department of Culture and Identity, Roskilde University.

2014 Linguistic Diversity in the International Workplace: Language Ideologies and Processes of Exclusion. Special issue ”Multilingualism at Work" Multilingua 33(1-2): 89-116.

2015 Language Ideologies in a Danish Company with English as a Corporate Language: 'It Has to Be English'. Journal of Multilingual \& Multicultural Development 36(4): 339-356. Millar, Sharon, Sylvie Cifuentes, and Astrid Jensen 
2013 A Social Representational Perspective on Languages and Their Management in the Danish Corporate Sector. In Exploring the Dynamics of Multilingualism. The DYLAN Project. Anne-Claude Berthoud, François Grin and Georges Lüdi, eds. Pp. 101-120. Amsterdam: John Benjamins.

Mortensen, Janus

2013 Notes on English Used as a Lingua Franca as an Object of Study. Journal of English as a Lingua Franca 2(1):25-46.

2014 Language Policy from Below: Language Choice in Student Project Groups in a Multilingual University Setting. Journal of Multilingual and Multicultural Development 35(4):425-442.

Nekvapil, Jiří, and Tamah Sherman

2013 Language Ideologies and Linguistic Practices: The Case of Multinational Companies in Central Europe. In Ideological Conceptualizations of Language: Discourses of Linguistic Diversity. Erzsébet Barát, Patrick Studer and Jiří Nekvapil, eds. Pp. 85-117. Frankfurt am Main: Peter Lang.

Ochs, Elinor 1999 Socialization. Journal of Linguistic Anthropology 9:230-233.

Ochs, Elinor and Bambi B. Schieffelin 2011 The Theory of Language Socialization. In the Handbook of Language Socialization, ed. Alessandro Duranti, Elinor Ochs and Bambi B. Schieffelin. Pp. 1-22. Malden: Wiley-Blackwell.

Rampton, Ben 2006 Language in Late Modernity. Cambridge: Cambridge University Press. Roberts, Celia 
2010 Language Socialization in the Workplace. Annual Review of Applied Linguistics 30:211-227.

Schieffelin Bambi B. and Elinor Ochs

1986 Language Socialization. Annual Review of Anthropology 15:163-91.

\section{Appendix: Transcription conventions}

Speaker ID:

LEIF

Overlapping speech:

「okay]

[who ] who are not

Pause in seconds:

Pause shorter than 0.5 seconds

(.)

Smiley voice:

(you know)

Emphasis:

$\underline{\text { Danish }}$

Pseudonym:

[company]

\begin{tabular}{|c|c|c|c|}
\hline Pseudonym & Nationality & Job description & $\begin{array}{l}\text { Language } \\
\text { competence }^{\mathrm{i}}\end{array}$ \\
\hline Morten & Danish & Head of department & $\begin{array}{l}\text { Danish, English, a } \\
\text { little German, } \\
\text { Swedish/Norwegian }\end{array}$ \\
\hline Leif & Danish & Project manager & English, Danish \\
\hline Sally & Canadian-Taiwanese & HR partner & $\begin{array}{l}\text { English, Mandarin, } \\
\text { French, Danish }\end{array}$ \\
\hline
\end{tabular}




\begin{tabular}{|l|l|l|l|}
\hline Anna & Danish & Communication & Danish, English \\
& partner & \\
\hline Isabel & Spanish & Training partner & Danish, English, \\
& & & Spanish, French \\
\hline
\end{tabular}

Table 1. Informants.

${ }^{\mathrm{i}}$ As reported in background questionnaires. 